\title{
WOOD MODIFICATION WITH FURFURYL ALCOHOL AND FURFURYLATED WOOD DURABILITY IN WATER
}

\author{
Andris Morozovs, Anete Keke, Lita Fisere, Uldis Spulle \\ Latvia University of Life Sciences and Technologies, Latvia \\ andris.morozovs@1lu.lv, kekeanete@gmail.com, litamfisere@gmail.com, uldis.spulle@1lu.lv
}

\begin{abstract}
Wood is renewable stock that is used for shield, heating and defence since the times men emerged. Wood product dimensional alterations are a serious drawback in the wood practical applications. These alterations are caused by atmospheric moisture absorbance into wood and water interaction with hemicelluloses and cellulose amorphous part hydroxyl groups to entail wood swelling or shrinking in the case of wood drying that leads to wood products cracking and properties loss. It is assumed that the accessible to water hydroxyl group's hydrogen atom substitution with more voluminous and less polar organic radical arouse wood permanent swelling or hydroxyl group shielding. Modified wood has less water absorption and diminished water equilibrium content (EMC) that is considered as the main reason of biological resistance improvement. Wood furfurylation with furfuryl alcohol $(F A)$ catalysed with maleic anhydride $(M A)$ is one of the wood modification approaches. Wood dimensional stability and biological resistance to decay increase by modification with furfuryl alcohol $F A$ is assumed as a result of $F A$ polymers grafting to cell wall polymers. Sufficient amount of $F A$ must be infused into wood cell walls, but $F A$ diffusion into the wood cell wall might be hampered by formation of more voluminous $\pi$-complex between $M A$ and $F A$ that favour useless polymerisation in wood voids and increased $F A$ and $M A$ consumption. The objective of the given research was to attain maximal modification of the wood cell wall by saturation with $F A$ and subsequent its polymerization by catalysis with formic acid vapour. Assessment of furfurylated and reference wood specimens durability in hot water - freezing - drying treatment was tested by the cyclic hydrothermal treatment $(\mathrm{CHT})$ test. Wood furfurylation decreased water absorption by $80 \%$ and swelling by $40 \%$ during CHT in comparison with untreated wood.
\end{abstract}

Keywords: cyclic hydrothermal tests, formic acid, furfuryl alcohol, wood.

\section{Introduction}

"We are touching with the two major issues in our time, man caused climate change and soaring world population. To construct adequate housing for future generations we must reinvent constructions so that we can fulfil this need with the minimum effect on environment" [1]. A great quantity of $\mathrm{CO}_{2}$ is emitted through the different phases of a building life cycle: in the production of materials and products, in construction of the building itself, in setting on site, in exploitation, the renovations, later rehabilitations, up to the final demolition [2]. In time of depleting fossil oil deposits it is obvious that the utilization of renewable raw materials is one necessary step towards a sustainable development. Wood, as a renewable resource, is available in vast quantities and has been widely used since time immemorial to provide people with shelter and heat. Wood is anisotropic with respect to its dimensional changes with the changing moisture content [3]. It has low resistance to bio-deterioration against fungi, termites, marine borers [4]. Like other biological materials, wood is susceptible to environmental deterioration and low resistance to UV irradiation $[5 ; 6]$.

Wood as a natural product that originates from different individual trees needs to be transformed to acquire the desired functionality by modification $[7 ; 8]$. The wood modification industry is currently undergoing major developments, driven in part by environmental concerns regarding the use of wood treated with certain classes of preservatives $[7 ; 8]$. Wood modification technologies: thermal modification [9;10], acetylation, and furfurylation [11] have been introduced in the market.

Wood furfurylation researches were initiated in the fifties in the previous century $[12 ; 13]$ by impregnation of wood consecutively with zinc chloride catalyst and furfuryl alcohol $(F A)$. Zinc chloride catalyst has drawbacks. It as salt of strong acid hydrolyses by moisture and forms hydrochloric acid that decomposes wood. At the beginning of the 1990s the cyclic anhydrides organic acids have been used to catalyse $F A$ polymerisation due to good solubility in $F A$ [14].

The furfurylated wood technology research up-scaling [15] was finalized on industrial production of furfurylated wood by Norwegian company AS Kebony [11]. According to the US patent [16] hardwood species boards are vacuum-impregnated with $5 \%$ solution of $M A$ in $F A$ and are cured at $95^{\circ} \mathrm{C}$ for $2 \mathrm{~h}$ followed by $3 \mathrm{~h}$ at $140^{\circ} \mathrm{C}$. Irrespective of the success of wood furfurylation on industrial 
scale, the researches of wood furfurylation chemistry fundamentals, technology improvements and furfurylated wood properties assessment are continued.

The objectives of the present research were: 1) to attain maximal saturation of the wood cell wall with $F A$ and catalysis with formic acid vapours; 2) evaluation of the modified wood cell wall interaction with water by the cyclic hydrothermal tests.

\section{Materials and methods}

Wood specimens furfurylation. Pine (Pinus Sylvestris L.) heartwood specimens (100 mm x $100 \mathrm{~mm} \times 20 \mathrm{~mm}^{3}$ (the grain, predominant tangential and radial direction) were cut-off from selected timber without faults and dried in a ventilated oven at $103 \pm 2{ }^{\circ} \mathrm{C}$ (Memmert GmbH Germany) for 2 days. Specimens were weighted on the electronic balance (Kern $\mathrm{GmbH})$ with precision $\pm 0.01 \mathrm{~g}$ and measured with the electronic digital calliper $\pm 0.1 \mathrm{~mm}$ ( 2 measurements in wood grain, 3 measurements in the width and 6 measurements in the specimen's thickness directions). The measurement values in the each direction were averaged and used to calculate the specimen's volume. Specimens sets with bamboo rods with diameter $2 \mathrm{~mm}$ spacers were immersed in furfuryl alcohol in a tightly covered polyethylene box. Specimens before weighing and measuring after the 2-th, 5-th, 7-th, 13-th, 16-th, 19-th, 26-th, 50-th and 69-th day were taken off from FA and placed on the glass road under the box to flow down furfuryl alcohol and then wiped with cotton cloth. The number of parallel specimens in the series was 10. In an analogue way was done furfuryl alcohol absorption in the pine wood 10 samples series with the initial moisture content $13.4 \%$. The both series of specimens were conditioned in the closed box at room temperature during 3 month for additional furfuryl alcohol diffusion into the wood cell wall. Then the specimens were conditioned in a desiccator during 1 day at $100{ }^{\circ} \mathrm{C}$ to eliminate $F A$ excess from the wood cavities. Wood furfurylation was realized by impregnated in wood $F A$ polymerization with formic acid vapours in a desiccator above liquid formic acid at $100{ }^{\circ} \mathrm{C}$ during 1 day. Finally the specimens were dried in the ventilated oven for 3 days at $103^{\circ} \mathrm{C}$.

Cyclic hydrothermal test. The dried till constant mass in the ventilated oven at $103 \pm 1{ }^{\circ} \mathrm{C}$ modified and reference unmodified pine specimens were tested in the cyclic hydrothermal test (CHTT) according to the parameters shown in Fig.1. Specimens were weighed and measured before and after immersion in hot water. The collapsed by cracking specimens were discarded. Masses and volumes of the sample data were smoothed with the weighted sliding average [17]. Wood sample mass or volume data were rationed against untreated, oven-dried mass or volume before treatments.

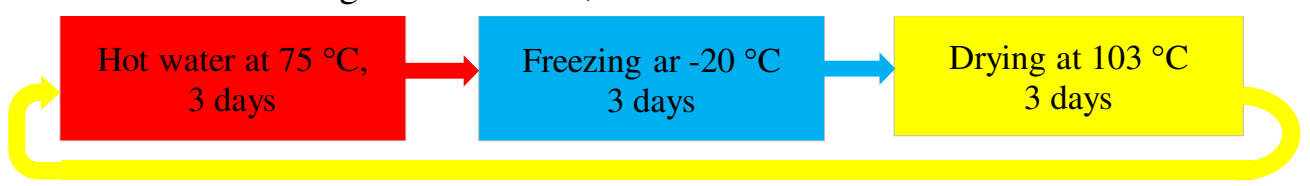

Fig.1. Cyclic hydrothermal test stage sequence and parameters

\section{Results and discussion}

Wood dimensional instability is caused by wood swelling or shrinking due to water absorption or desorption due to its interaction with wood component hydroxyl groups [3]. It can be prevented by wood hydroxyl group modification or shielding. Mostly $M A[11 ; 15]$ is used as catalyst in the wood furfurylation. $M A$ has $\pi$-electron deficit double bond due to electron acceptor character of the anhydride functional group. On the other hand, $F A$ has a five member heterocyclic system with increased $\pi$-electron density that might lead to $\pi$-electron donor-acceptor complex formation between $M A$ and $F A$. Such complex is precursor of Diels-Alder cycloadditions [18]. Formation of such more voluminous complex as well as furfuryl hydrogen maleate formation by anhydride reaction with $F A$ will decrease probability of its penetration into the wood cell wall that is necessary for wood protection against interaction with water. Water molecules have less molecule volumes than $F A$ as shown by calculation in Eq. 1, and therefore higher possibility to penetrate into the wood cell wall. On both these theoretical hypothesis the choice of two stage wood furfurylation was based consisting of: the first stage wood cell wall maximal saturation with $F A$ and the second one $-F A$ polymerization with formic acid vapour catalyst. 


$$
M V R=\frac{M V_{F A}}{M V_{w}}=\frac{M_{F A} \cdot \rho_{w}}{M_{w} \cdot \rho_{F A}}=\frac{98.1 \cdot 1}{18.02 \cdot 1.13}=4.82,
$$

where $M V R-$ molecular volume ratio;

$M V_{F A}-F A$ molecule mass, $\mathrm{kg} \mathrm{mol}^{-1}[19]$;

$M V_{w}$ - water molecule mass, $\mathrm{kg} \mathrm{mol}^{-1}[20]$;

$\rho_{w}$ - water density, $\mathrm{kg} \mathrm{m}^{-3}[20]$;

$\rho_{F A}-F A$ density, $\mathrm{kg} \mathrm{m}^{-3}[19]$.

Wood cell wall saturation with $\boldsymbol{F A}$. Diffusion is a molecular flow inside solid substance and it is many orders slower than the liquid flow in wood voids: traheids and capillaries. Diffusion velocity is not influenced by pressure that is why the extended wood specimen impregnation with $F A$ in immersed condition and continuous after-conditioning were selected. The pine wood specimens series with different moisture content: the first one was oven-dried with the moisture content about $0 \%$ and the second series with the moisture content $13.6 \%$ that is approximately near to EMC of freely dried wood.

FA absorption into oven-dried wood specimens and specimens with the initial moisture content (MC) $13.4 \%$ were calculated according to Eq.2 and the mean values of the $F A$ absorption are presented in Fig. 2.

$$
A=\left(\frac{m_{i}}{m_{i, 0}}-1\right) \times 100
$$

where $A-F A$ absorption in wood, \%;

$m_{i}-$ current mass of wood specimen in weighing $(i), \mathrm{g}$;

$m_{i, 0}-$ dried specimen mass before $F A$ absorption, $\mathrm{g}$.

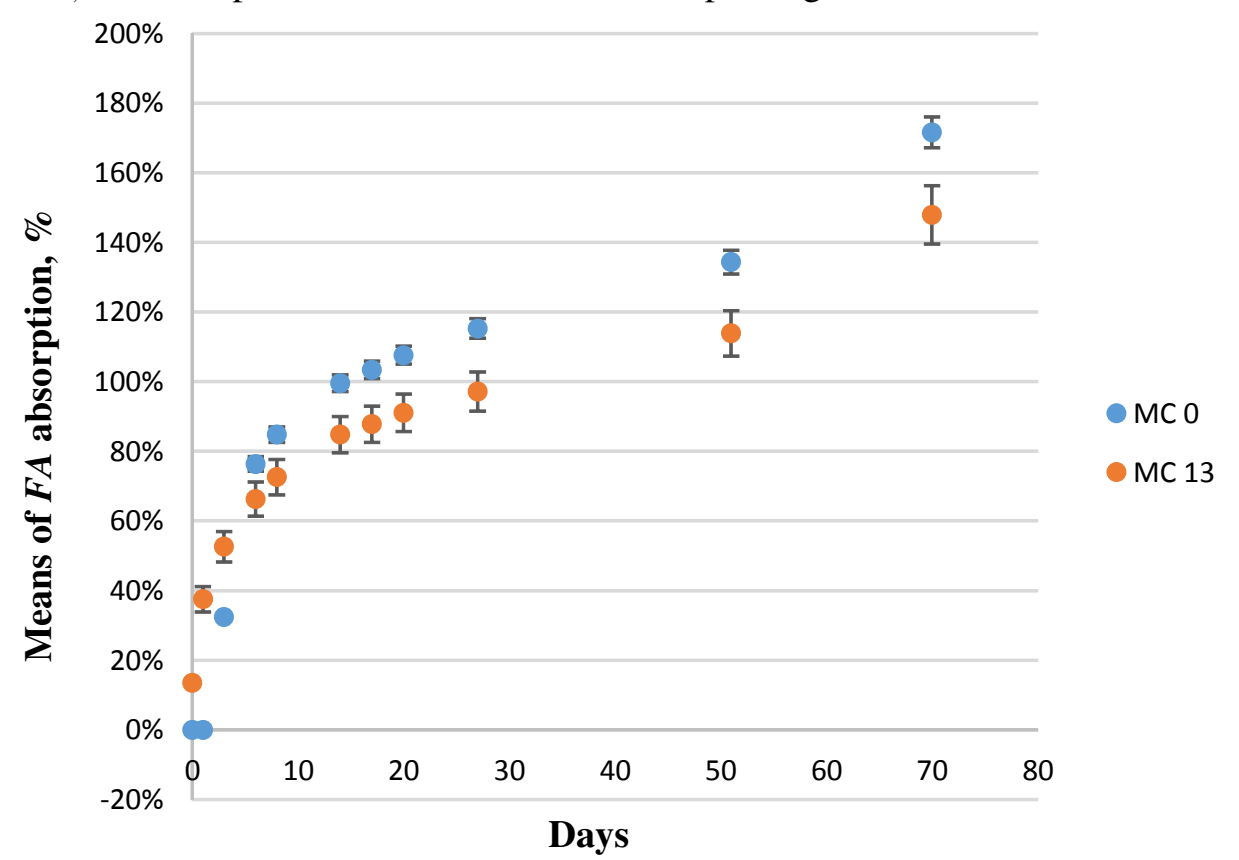

Fig. 2. Mean values of $F A$ absorption into pine wood specimens with initial $\mathrm{MC} 0=0 \%$ and equilibrium MC $13=13.4 \%$

$F A$ absorption into the oven dried wood specimens had an induction period of $F A$ absorption that might be caused by trapped air and wood swelling in $F A$. Absence of wood swelling in the neat $F A$ in comparison with different concentration $M A$ solution in $F A$ was observed by Herold, et al. [21]. In general $F A$ absorption in the oven-dried wood after the induction period was faster and absorbed $F A$ mass was higher than of wood with EMC (Fig. 2). $F A$ and wood absorb moisture from environment during weighing and measuring that alters properties of both, $F A$ and wood. The $F A$ solubility in water is $100 \mathrm{mg} \cdot \mathrm{ml}^{-1}$ [19]. The influence of the environment moisture during the impregnated specimen 
measurements was detected by mass alterations according to Eq. 3 during 237 days long conditioning of the impregnated with $F A$ specimens as shown in Fig. 3.

$$
\Delta M=\left(\frac{m_{i}}{m_{s}}-1\right) \times 100
$$

where $\Delta M-$ wood specimen mass alteration during conditioning, $\%$;

$m_{i}$ - current mass of wood specimen in weighing $(i), \mathrm{g}$;

$m_{s}$ - mass of wood specimen at the start of conditioning, $\mathrm{g}$.

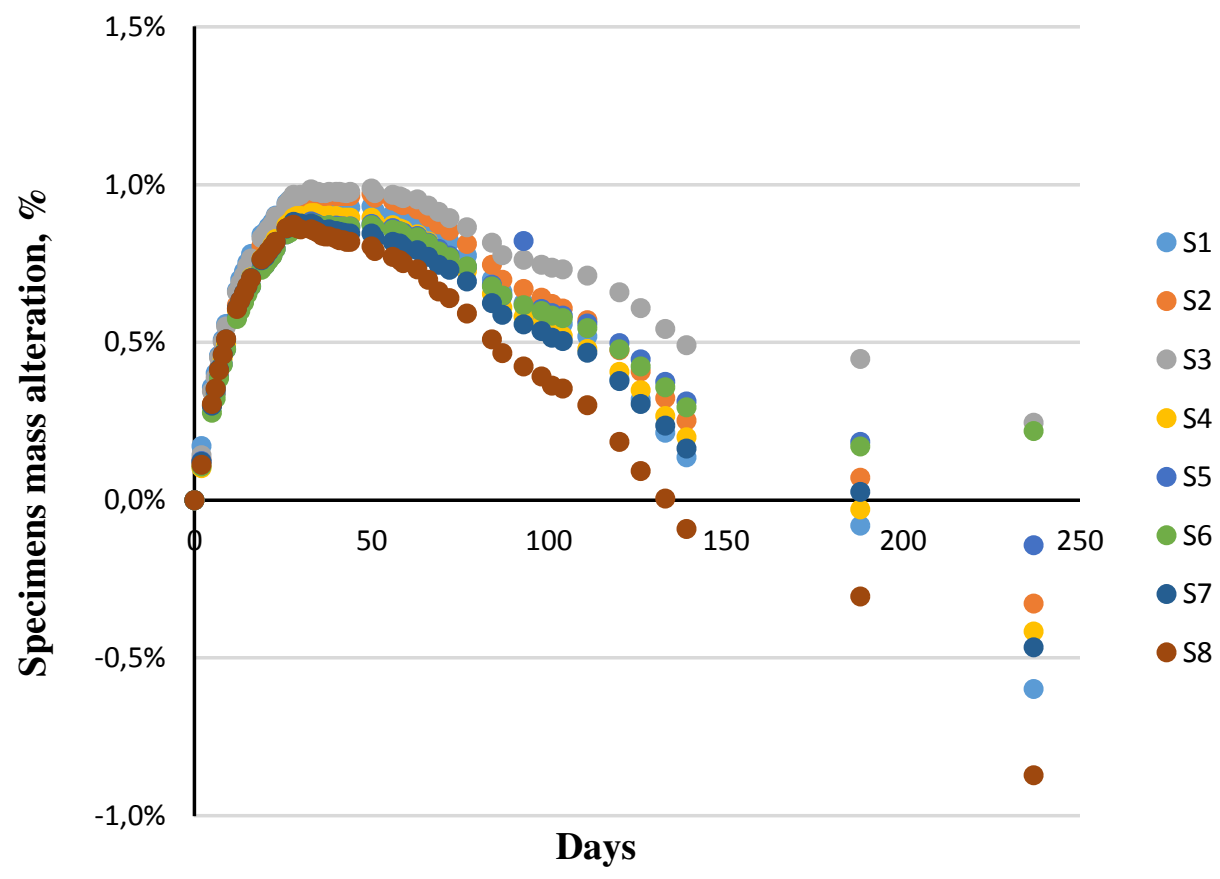

Fig. 3. Wood specimens (S1-S8) with initial MC = 0 \% mass alteration during conditioning

In case of oven-dried pine wood impregnated with $F A$ specimen conditioning the wood mass increase in the first month of exposition was due to water absorption rate superiority over $F A$ desorption rate that was followed by both processes equilibrium during the next month of conditioning. Hereafter, the specimen mass decreased due to $F A$ desorption superiority over water absorption from environment.

The $F A$ molecule has the alcohol functional group that can participate as electron and hydrogen donor in formation hydrogen bond with the hemicellulose or cellulose hydroxyl group that will result in wood swelling. The wood volume swelling was calculated with Eq. 3.

$$
S=\left(\frac{V_{i}}{V_{0}}-1\right) \times 100
$$

where $S$-wood specimen volume swelling, $\%$;

$V_{i}$ - current wood specimen volume, $\mathrm{cm}^{3}$;

$V_{0}$ - oven dried un-treated wood specimens volume $\mathrm{cm}^{3}$

Oven-dried wood specimens swelling in $F A$ at the end of the first week of absorption was $12 \%$ in average that increased only by $1 \%$ during the subsequent 8 weeks.

Impregnated $\boldsymbol{F A}$ polymerization. Wood furfurylation with $F A$ commonly is catalysed with $M A$ $[11 ; 14-16 ; 22]$. Actual catalyst is maleic acid, formed in $M A$ reaction with water in wood, or acidic $M A$ and $F A$ monoester formed in reaction between $F A$ and $M A$. The both reactions are initiated by heating. Formic acid $(F A c)$ was chosen for in advance impregnated $F A$ polymerization due to its smaller than $F A$ molecule volume. FAc boiling temperature is $101{ }^{\circ} \mathrm{C}$ [23] that is acceptable 
temperature for wood furfurylation. The reaction time was increased from few hours till one day due to 1.9 order lower acidity of formic acid in comparison with maleic acid.

Cyclic hydrothermal tests. Water molecules were used as probes to assess the wood cell wall protection by FA polymers in the CHT due to their small molecule volume. Water molecules having small volume might penetrate between $F A$ polymer and the wood cell wall components in case of absence of bonding between them. The hot water absorption calculated according Eq. 2 in the reference wood was more than 3 times greater in comparison with the furfurylated wood during the initial CHT cycles. It can be supposed that less water absorption in the furfurylated wood is the result of wood voids filling with $F A$ polymer or blocking water flow into voids [14]. The water absorption increase of the furfurylated wood during the latest CHT might be the result of these blocked wood voids opening (Fig 4). Water anti-absorption efficiency was calculated to evaluate the wood furfurylation efficiency according to Eq. 4.

$$
A A E=\left(1-\frac{A_{F}}{A_{R}}\right)
$$

where $A A E$ - water anti-absorption efficiency, \%;

$A_{F}$ - water absorption in the furfurylated wood according Eq. 2, \%

$A_{R}$ - water absorption in the reference wood according Eq. 2, \%.

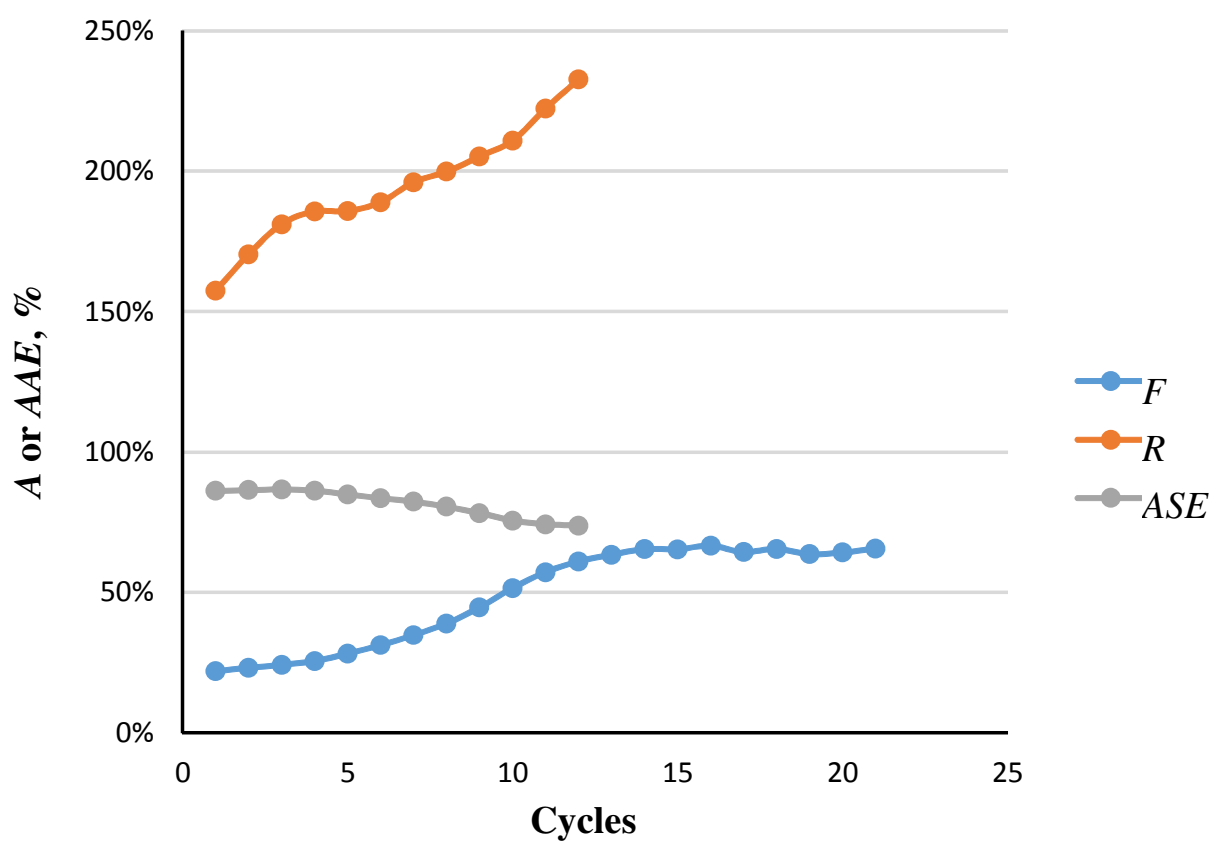

Fig. 4. Water absorption $(A)$ in furfurylated $(F)$, reference $(R)$ wood and anti-absorption efficiency $(A A E)$ alterations during CHT

The water absorption amount is mainly determined by wood voids filling in contrary to wood swelling that is determined by water interaction with the cell wall. Possible $F A$ polymer grafting with wood components or the bulking effect decreased the furfurylated wood swelling in comparison with the reference one (Fig. 5). Anti-swelling efficiency (ASE) of wood furfurylation decreases from $42 \%$ to $33 \%$ during $11 \mathrm{CHT}$ cycles. ASE value for furfurylated wood was 1.7 times lesser in comparison with acetylated wood in analogue CHT tests. The reference wood to furfurylated wood swelling ratio diminished from 1.7 to 1.5 .

$$
A S E=\left(1-\frac{S_{F}}{S_{R}}\right)
$$

where $A S E$ - anti-swelling efficiency, \%;

$S_{F}$ - furfurylated wood swelling, \%;

$S_{R}-$ reference wood swelling, $\%$. 
The furfurylation efficiency in wood protection against water absorption and swelling in water in comparison with natural wood practically did not altered during the first five CHT cycles and then decreased by less than $10 \%$ during the next seven cycles that is the result of wood protection by furfurylation diminishing during CHT due to water penetration into the wood cell wall and its structure change.

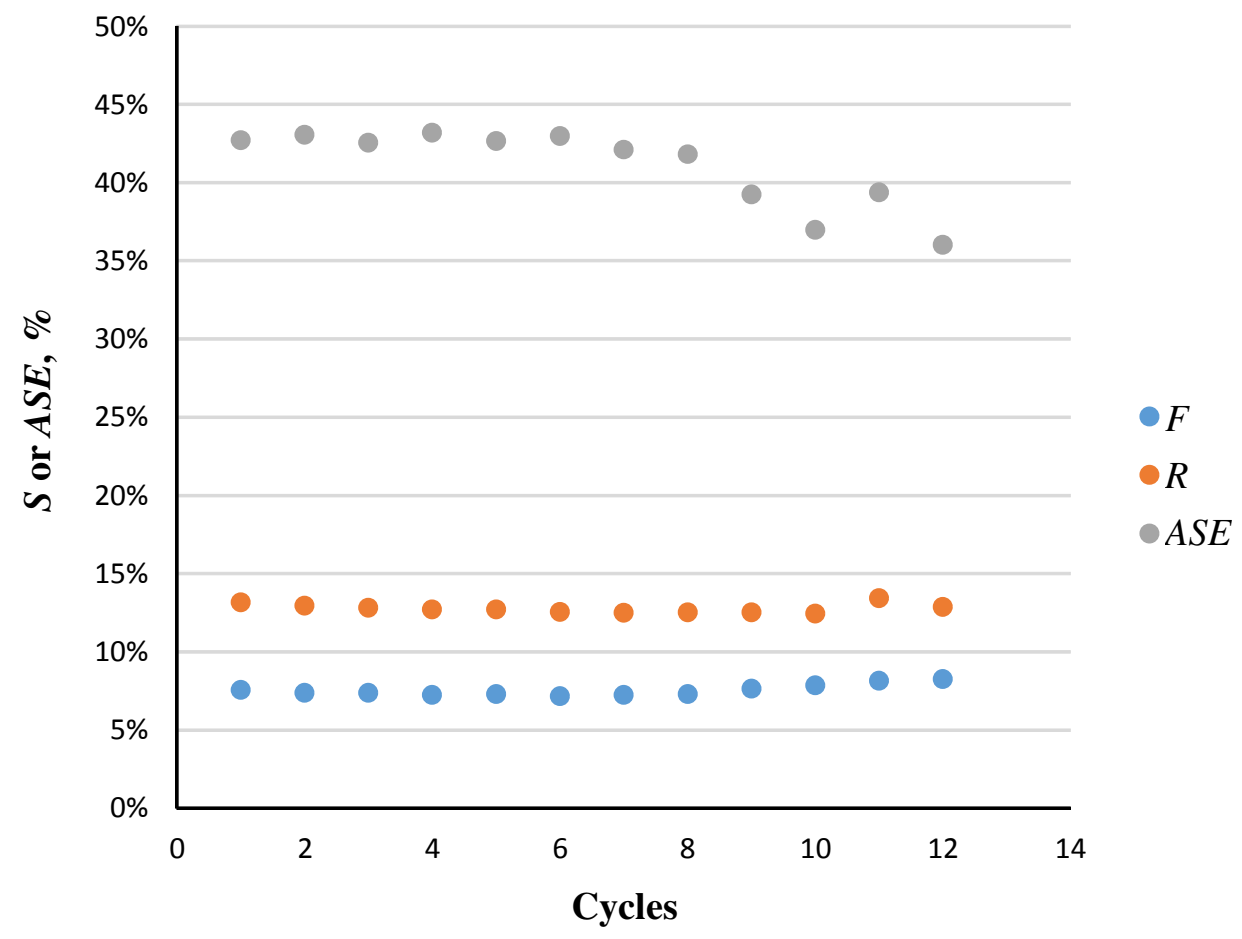

Fig. 5. Furfurylated $(F)$ and reference $(R)$ wood swelling $(S)$ and anti-swelling efficiency $(A S E)$ alteration during CHT

\section{Conclusions}

Pine wood (Pinus Silvestris L.) was furfurylated by a two stage process. In the first stage wood was impregnated with furfural alcohol with long-term immersion, then conditioned to favour furfural alcohol diffusion into the wood cell wall at room temperature. One day conditioning at $100{ }^{\circ} \mathrm{C}$ was used to extract surplus furfural alcohol from wood tracheids before furfurylation. Wood furfurylation was realized by catalysis with formic acid vapours at $100{ }^{\circ} \mathrm{C}$ with subsequent drying in the oven at $103^{\circ} \mathrm{C}$. Mas increase by modification was $128 \pm 3 \%$. Cyclic hydrothermal test was composed of hot water at $75^{\circ} \mathrm{C}$, freezing at $-20^{\circ} \mathrm{C}$ and drying at $103^{\circ} \mathrm{C}$ treatments with duration for 3 days of each treatment stage. Wood furfurylation decreased in average water absorption by $80 \%$ and swelling by $40 \%$ in comparison with untreated wood during the CHT.

\section{Acknowledgements}

The research was financially supported by the National Research Programme: "Forest and earth entrails resources: research and sustainable utilization - new products and technologies (ResProd)" and was coordinated with the COST Action FP 1407.

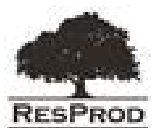

\section{References}

[1] Mayo J. Solid woos Case studies in mass timber architecture, technology and design. New York: Routledge, 2015. 345 p. 
[2] Gonzalez M.J., Navarro J.G. Assessment of the decrease of $\mathrm{CO} 2$ emissions in the construction field through the selection of materials: Practical case study of three houses of low environmental impact. Building and Environment, vol. 41, 2006, pp. 902-909.

[3] Skaar C. Wood-water relations. Berlin, Heidelberg, New York, London, Paris, Tokyo: SpringerVerlag, 1988. 283 p.

[4] Eaton R.A., Hale M.D.C. Wood: decay, pests and protection. London, New York: Chapman \& Hall, 1993. 546 p.

[5] Cogulet A., Blanchet P., Landry V. Wood degradation under UV irradiation: A lignin characterization. Journal of Photochemistry \& Photobiology, B: Biology, vol. 158, 2016, pp. 184-191.

[6] Chang S.-T., Hon D.N.-S., Feist W.C. Photo degradation and photo protection of wood surfaces. Wood and Fiber, vol. 14, 1982, pp. 104-117.

[7] Sandberg D., Kutnar A., Mantanis G. Wood modification technologies - a review. iForest: Biogeosciences and Forestry, vol. 10, 2017, pp. 895-908.

[8] Hill C.A.S. Wood modification. Chemical thermal and other processes. Chippenham, Wilshire: John Wiley \& Sons, 2006. 239 p.

[9] Pelaez-Samaniego M.R., Yadama V., Lowell E., Espinoza-Herrera R. A review of wood thermal pre-treatments to improve wood composite properties. Wood Science and Technology, vol. 47, 2013. pp. 1285-1319.

[10] Esteves B.M., Pereira H.M. Wood modification by heat treatment: A review. BioResources, vol. 4, 2009, pp. 370-404.

[11] Mantanis G.I. Chemical modification of wood by acetylation or furfurylation: A review of the present scale-up technologies. BioResources, vol. 12, 2017, pp. 4478-4489.

[12] Goldstein I.S., Dreher W.A. Stable furfural alcohol impregnating solution. Industrial \& Engineering Chemistry Research, Vol. 52, 1960. pp. 57-58.

[13] Stamm A.J. Dimensional stabilization of wood with furfuryl alcohol resin. Chapter 9. In: Goldstein I. (ed.) Wood Technology: Chemical Aspects. ACS Symposium Series. Vol. 43, Washington: ACS Publications, 1977. pp. 141-149.

[14]Lande S., Eikenes M., Westin, M. Chemistry and ecotoxicology of furfurylated wood. Scandinavian Journal of Forest Research, vol. 19, 2004, pp. 14-21.

[15] Lande S., Westin M. and Schneider M. Properties of furfurylated wood. Scandinavian Journal of Forest Research, vol. 19, 2004, pp. 22-30.

[16] Schneider M.H. Furan polymer impregnated wood, method for preparing the polymer and uses thereof. US Patent No.: US 8,197.948 B2, 2012.

[17]Liepa, I. Biometrija. (Biometry) Riga: Zvaigzne, 1974, 333 p. (in Latvian).

[18] Guigo N., Mija A., Vincent L. and Sbirrazzuoli N. Chemorheological analysis and model-free kinetics of acid catalysed furfuryl alcohol polymerization. Physical Chemistry Chemical Physics, vol. 9, 2007, pp. 5359-5366.

[19] Furfuryl alcohol. PubChem. Open Chemistry Database, Available at: https://pubchem.ncbi.nlm.nih.gov/compound/furfuryl_alcohol

[20] Water. PubChem. Open Chemistry Database, Available at: https://pubchem.ncbi.nlm.nih.gov/compound/water

[21] Herol N., Dietrich T., Grigsby W., Franich R.A., Winkler A., Buchelt B., Pfriem A. Effect of maleic anhydride content and ethanol dilution on the polymerization of furfuryl alcohol in wood veneer studied by differential scanning calorimetry. BioResources, vol. 8, 2013, pp. 1064 -1075.

[22] Epmeier H., Westin M., and Rapp A. Differently modified wood: Comparison of some selected properties. Scandinavian Journal of Forest Research, vol. 19, 2004, pp. 31-37.

[23] Formic acid. Open Chemistry Database, Available at: https://pubchem.ncbi.nlm.nih.gov/compound/formic_acid 